\title{
Persepsi WPOP Mengenai Diskriminasi Pajak, Pengetahuan Perpajakan, dan Norma Subjektif Terhadap Etika Penggelapan Pajak
}

\author{
Farah Nabilah, Masripah, Ratna Hindria DPS \\ Universitas Pembangunan Nasional "Veteran" Jakarta, \\ Jl. RS. Fatmawati Raya, Pd. Labu, Kec. Cilandak, Kota Depok, Jawa Barat 12450
}

\section{Kata Kunci:}

Diskriminasi pajak,

Pengetahuan perpajakan, Norma subjektif, dan Etika penggelapan pajak

Keywords:

Tax discrimination, Tax knowledge, Subjectif norm, and Ethical of tax evasion

Corresponding author: masripah@upnvj.ac.id

\begin{abstract}
ABSTRAK
Penelitian ini dilakukan untuk menguji dan mengetahui persepsi wajib pajak orang pribadi mengenai diskriminasi pajak, pengetahuan perpajakan, dan norma subjektif terhadap etika penggelapan pajak. Variabel independen yang digunakan dalam penelitian ini adalah diskriminasi pajak, pengetahuan perpajakan, dan norma subjektif. Populasi yang ada di dalam penelitian ini adalah seluruh wajib pajak orang pribadi yang terdaftar di KPP Pratama wilayah Jakarta, Bogor, Depok, Tangerang,dan Bekasi. Sampel yang ada dalam penelitian ini berjumlah 100 wajib pajak orang pribadi yang terdaftar di KPP Pratama wilayah Jakarta, Bogor, Depok, Tangerang,dan Bekasi. Teknik analis is data yang digunakan dalam penelitian Structural Equation Modeling (SEM) dengan menggunakan aplikasi Partial Least Square dengan tingkat signifikansi sebesar 5\%. Hasil dalam penelitian ini menunjukkan bahwa diskriminasi pajak berpengaruh positif signifikan terhadap etika penggelapan pajak, sedangkan untuk pengetahuan perpajakan dan norma subjektif tidak memiliki pengaruh yang signifikan terhadap etika pengge lapan pajak.
\end{abstract}

\section{ABSTRACT}

This research was conducted to examine and determine the perception of individual tax payers on tax discrimination, tax knowledge, and subjectif norm abaout the ethical of tax evasion. The independent variable used in this tax discrimination, tax knowledge, and subjectif norm. The population in this study was all individual taxpayers who are registered in KPP Pratama in Jakarta, Bogor, Depok, Tangerang, and Bekasi. The sample in this study amounted to 100 individual taxpayers who are registered in KPP Pratama in Jakarta, Bogor, Depok, Tangerang, and Bekasi. The data analysis technique used is Structural Equation Modeling (SEM), using the Partial Least Square application with a significance level of 5\%. The results of this study indicate that tax discrimination has a significant effect on the ethical of tax evasion, whereas tax knowledge and subjective norm has no significant effect on the ethics of tax evasion. 
Studi Akuntansi \& Keuangan Indonesia

\section{Pendahuluan}

Pemerintah melakukan pemungutan pajak pada wajib pajak orang pribadi (WPOP) menggunakan sistem self assessment system. Sistem yang diterapkan ini menguntungkan tugas pekerjaan pemerintah dalam menarik dana pajak. Keuntungan yang lainnya adalah lebih praktis dalam melakukan pembayaran pajak, agar masyarakat aktif dan lebih memahami perpajakan serta memiliki kesadaran dalam melakukan pembayaran pajak. Selain itu, sistem ini memiliki dampak yang negatif, karena dapat memberikan peluang masyarakat untuk melakukan penghindaran dan penggelapan pajak pada WPOP sehingga menimbulkan kerugian negara.

Timbulnya pemikiran yang negatif tentang pajak pada WPOP dapat menjadikan pelaku penggelapan (wajib pajak) tanpa diketahui oleh pelaku, mereka telah melakukan pelanggaran dalam suatu etika. Hal tersebut telah menandakan terjadinya kegagalan etis di kalangan negara khususnya pada pandangan masyarakat (Wulandari, Maslichah, \& Mawardi, 2019). Terdapat beberapa hal yang mendukung adanya persepsi wajib pajak terhadap tindakan penggelapan pajak adalah sesuatu yang beretika, diantaranya yaitu diskriminasi pajak. Pada saat melakukan pembayaran pajak yang dimana perlakukan pegawai pajak tidak seimbang terhadap perorangan maupun kelompok dengan yang lainnya mela lui pedoman atas status sosial, agama, etnik dan lain sebagainya.

Adanya wajib pajak yang merasa didiskriminasikan dengan cara pemotongan pajak pada $\mathrm{PPh}$ Pasal 21 bagi perempuan lebih besar dibandingkan pemotongan pajak PPh Pasal 21 bagi pihak lakilaki, di dalam berita yang dikeluarkan oleh www.koranperdjoeangan.com. Pada perhitungan gaji perempuan yang dipotong pajaknya oleh perusahaan, perempuan dianggap masih lajang (kenyataannya sudah menikah dan memiliki anak). Sedangkan saat menghitung pajak yang dipotong dari gaji laki-laki, perusahan telah menghitung penghasilan tidak kena pajak (PTKP) pada status lakilaki yang telah menikah dan telah mempunyai anak. WPOP yang merasa terdiskriminasi terkait hal tersebut menjadikan sebab masyarakat tidak patuh dan tidak tertib dalam pembayaran wajib pajak, serta dapat dikategorikan bahwa masih terdapat masyarakat yang masih kurang dalam pengetahuan tentang perpajakan. Suami istri yang keduanya bekerja dalam perhitungan pajak penghasilan akan digabungkan terlebih dahulu dalam perhitungan. Sehingga, agar tidak terjadi penggandaan perhitungan PTKP, perusahaan hanya akan menghitung PTKP pada karyawan laki-laki yang sudah menikah.

Faktor lain dari persepsi WPOP dalam tindakan penggelapan pajak yang menjadikan sesuatu beretika adalah norma subjektif. Seseorang yang berpersepsi mengenai tekanan sosial untuk bertindak atau tidak bertindak dengan niat yang tergantung pada norma subjektif. Dimana norma subjektif yang tinggi mempengaruhi WPOP dalam berpersepsi, niat yang ada dalam diri WPOP untuk melakukan pengge lapan pajak dimana akan merugikan dirinya dan juga merugikan negara atas tindakan yang dilakukan (Wanarta \& Mangoting, 2014). 
Studi Akuntansi \& Keuangan Indonesia

Berdasarkan fenomena yang penulis jelaskan sebelumnya, maka diperlukan penelitian untuk memperkuat faktor-faktor yang berpengaruh terhadap etika penggelapan pajak. Hal ini yang mendorong penulis untuk melakukan penelitian terkait pengaruh diskriminasi pajak, pengetahuan perpajakan dan norma subjektif terhadap etika pengge lapan pajak dalam persepsi wajib pajak orang pribadi.

\section{Telaah Lite ratur dan Pengembangan Hipotesis}

\subsection{Theory of Planned Behavior}

Tingkah laku yang dilakukan oleh seseorang secara rasionalitas dan yang dilakukan di bawah kontrol dari kesadaran seseorang yang dinamakan dengan Theory of planned behavior. Seorang Ajzen pada tahun 1991, mengembangkan sebuah teori yaitu Theory Of Reasoned Action (TRA) diubah membentuk Theory Of Planned Behavior (TRB) dengan tujuan dan maksud untuk mengaitkan antara ikatan dengan perilaku yang dilakukannya pada setiap orang. Perilaku individu biasanya dipengaruhi oleh niat yang ada di hati seseorang terhadap suatu perilaku tertentu. Dari pendapat Ajzen (2005), membagi beberapa tolak ukur dalam memprediksi pada bagian utama yang dapat mempengaruhi niat dari seseorang untuk me lakukan suatu tindakan yakni sikap terhadap suatu hal perilaku, persepsi terkait pengontrolan perilaku, dan norma subjektif pada suatu perilaku tertentu. Hubungan antara penelitian ini dengan teori tersebut terletak pada tiga komponen dalam theory of planned behavior (Ajzen, 1991) yaitu:

a. Behavioral beliefs, keyakinan akan hal mengenai kemungkinan atas terjadinya perilaku tertentu, dengan kata lain bahwa hasil dari keyakinan yang ada di dalam tiap personal atas suatu perilaku dan evaluasi. Pada TRA sendiri hal ini disebut sikap yang dimiliki oleh perilaku individu, yang dimana dapat dilihat dari tindakan atau perilaku yang dimiliki oleh aparat pajak untuk melakukan pendiskriminasian pajak atas orang-orang tertentu, maka hal tersebut dapat membuat suatu penilaian negatif yang dimiliki oleh masyarakat atas tindakan hal tersebut dan akan melakukan penggelapan pajak dengan cara apapun, seperti memalsukan data mereka, menunda pembayaran, dan masyarakat akan beranggapan bahwa tindakan tersebut etis untuk dilakukan.

b. Normative beliefs, yakni suatu keyakinan pada harapan bersifat normatif yang muncul disebabkan oleh pengaruh dari seseorang serta dorongan motivasi dalam memenuhi harapan. Pada TRA disebut dengan norma subjektif. Pengaruh dorongan motivasi dari orang-orang dekat dan orang yang ada disekitar memberikan pengaruh yang sangat signifikan untuk seseorang tersebut melakukan wajib pajak secara patuh (Wanarta \& Mangoting, 2014).

c. Control beliefs, merupakan keyakinan pada kehadiran yang mendorong maupun memperlambat perilaku yang diperlihatkan dan penilaian serta pertimbangan keadaan tersebut dapat 
Studi Akuntansi \& Keuangan Indonesia

mendukung maupun menghambat perilaku yang dilakukan oleh seseorang. Hal tersebut dapat dinilai dalam mendukung atau menghambat perilaku pada diri sendiri sesuai dengan pengetahuan yang berkaitan dengan perpajakan. Hambatan yang mungkin dapat terjadi berasal dari diri sendiri yang masih awam terkait pengetahuan tentang pajak.

\subsection{Pengembangan Hipotesis}

\subsubsection{Pengaruh Diskriminasi Pajak Terhadap Etika Pengge lapan Pajak Dalam Persepsi Wajib Pajak Orang Pribadi}

Peraturan pemerintah dalam hal perpajakan secara tidak adil menimbulkan diskriminasi dalam bidang perpajakan itu sendiri. Menurut Silaen (2015), dalam peraturan tersebut menunjukkan adanya sebuah keuntungan pada pihak-pihak tertentu saja, dalam artian menimbulkan tindakan diskriminasi terhadap seluruh wajib pajak.

Dalam telaah yang dilakukan Dewi dan Merkusiwati (2017), serta Monica dan Arisman (2018) menunjukkan hasil bahwa diskriminasi pajak mendapatkan pengaruh positif pada etika penggelapan pajak. Berbeda dengan hasil riset studi yang dilakukan oleh Pratiwi dan Prabowo (2019) serta Putri (2017) yang mendapatkan hasil tindakan diskriminasi pajak tidak berpengaruh atas suatu tindakan tentang etika penggelapan pajak, selama masih adanya suatu indikasi dari wajib pajak untuk menjalankan kegiatan atas pelunasan pajak dan indikasi yang lain berupa mematuhi peraturan undang-undang yang sudah dibuat pemerintah terkait perpajakan serta mempunyai tingkat kesadaran atau patuh untuk hal pembayaran pajak. Adapun hipotesis yang terdapat pada penelitian ini yang berdasarkan dari uraian di atas, adalah sebagai berikut:

$\mathrm{H}_{1}$ : Diskriminasi pajak memiliki pengaruh terhadap etika pengge lapan pajak dalam persepsi wajib pajak orang pribadi.

\subsubsection{Pengaruh Pengetahuan Perpajakan Terhadap Etika Penggelapan Pajak Dalam Persepsi Wajib Pajak Orang Pribadi}

Seseorang dapat mengubah kebiasaan dalam kaitannya perilaku manusia melalui pelatihan ataupun pengajaran. Hal ini dikarenakan seorang individu tersebut memiliki pengetahuan. Sehingga bila sekelompok wajib pajak atau seseorang individu yang memiliki kewajiban membayar pajak memiliki pengetahuan terkait perpajakan, maka pengetahuan tersebut dapat mendorong individu untuk menjalankan kewajibannya. Sesuai dengan penelitian Febri dan Sulistiyani (2018) yang menyatakan bahwa melalui pendidikan formal maupun tidak formal masyarakat bisa saja memperoleh pengetahuan tentang perpajakan dan hal itu akan berdampak positif pada tingkat kesadaran kelompok atau individu yang memiliki kewajiban wajib pajak untuk membayar pajak. 
Studi Akuntansi \& Keuangan Indonesia

Dalam penelitian yang dilakukan oleh Putri (2017) serta Febri dan Sulistiyani (2018) mendapatkan hasil bahwa pengetahuan perpajakan berpengaruh positif terhadap etika pelanggaran pajak. Penelitian yang dilakukan oleh Solekhah dan Supriono (2018) serta Kwarto dan Zulhamzi (2019) menyatakan bahwa pengetahuan perpajakan tidak memiliki pengaruh terhadap kepatuhan pajak yang nantinya akan menimbulkan tindakan penghindaran pajak ataupun penggelapan pajak. Dengan demikian, hipotes is kedua dalam penelitian ini yaitu:

$\mathrm{H}_{2}$ : Pengetahuan perpajakan memiliki pengaruh terhadap etika penggelapan pajak dalam persepsi wajib pajak orang pribadi.

\subsubsection{Pengaruh Norma Subjektif Terhadap Etika Penggelapan Pajak Dalam Persepsi Wajib Pajak Orang Pribadi}

Dalam riset studi yang dilakukan oleh Wanarta dan Mangoting (2014) mengenai norma subjektif serta etika penggelapan pajak memiliki hasil bahwasanya norma ini sendiri memiliki cukup pengaruh yang signifikan positif dengan niat dari wajib pajak untuk melakukan aksi penggelapan pajak atau etika penggelapan pajak. Seiring dengan telaah yang dilakukan oleh Alvin (2014) yang mengungkapkan bahwa kepatuhan wajib pajak yang signifikan terjadi dari adanya norma subjektif. Norma subjektif sendiri dipengaruhi dari orang-orang sekitar dan juga orang-orang terdekat termasuk konsultan perpajakan, rekan kerja, teman, keluarga, serta hal lainnya yang bisa mengubah atau berpengaruh dalam niat ataupun perilaku wajib pajak dalam melakukan kewajibannya.

Berbeda dari pada hasil penelitian yang dilakukan oleh Surahman dan Putra (2018) serta Fatimah dan Wardani (2017) yang menyatakan hasil bahwa norma subjektif tidak memiliki pengaruh terhadap tindakan pengge lapan pajak. Dalam hal ini penulis memiliki hipotesis yang ketiga da lam penelitian ini hal tersebut didapatkan dari uraian di atas, hipotes is tersebut, yaitu:

$\mathrm{H}_{3}$ : Norma subjektif memiliki pengaruh terhadap etika pengge lapan pajak dalam persepsi wajib pajak orang pribadi.

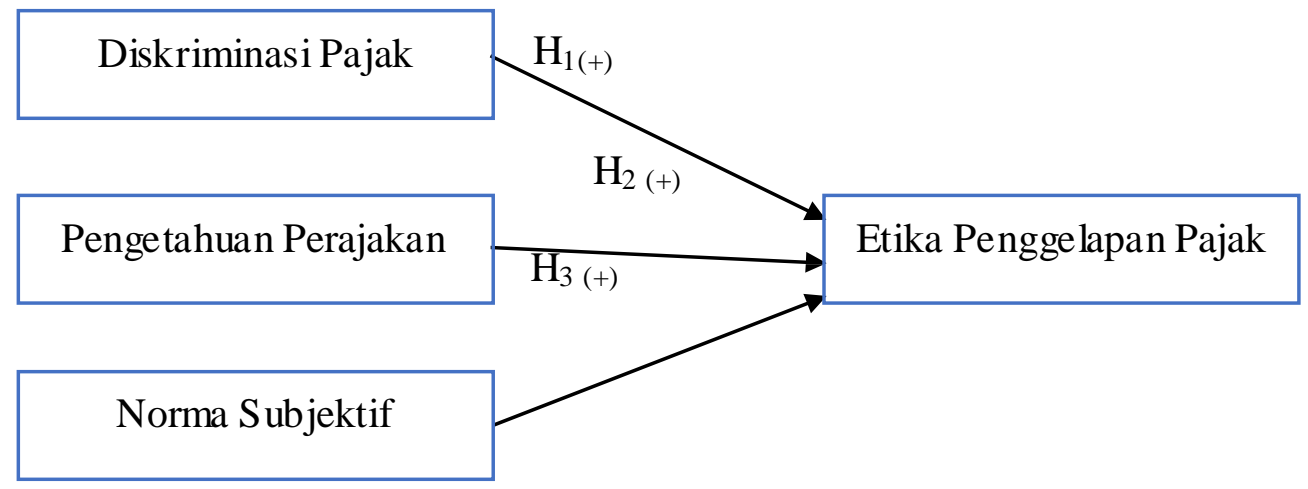


Studi Akuntansi \& Keuangan Indonesia

\section{Gambar 1 Kerangka Pemikiran}

\section{Metode Penelitian}

Definisi operasional dan juga indikator yang dipergunakan pada penelitian ini yaitu:

a. Variabel Dependen (Y)

Variabel dependen pada penelitian ini ialah etika penggelapan pajak. Bagaimana wajib pajak menganalisis, memaknai dari perilaku individu yang menyangkut tentang penggelapan pajak serta terjadi di lapangan dengan selalu mempertimbangkan berbagai faktor tertentu serta yang terakhir mengorganisir presepsi wajib pajak tentang atau mengenai penggelapan pajak (Dewi \& Merkusiwati, 2017). Instrumen pertanyaan (lihat Tabel 1) yang dikembangkan oleh Silaen (2015) dipakai pada penelitian ini untuk variabel etika penggelapan pajak dan menggunakan skala likert (sangat tidak setuju skor 1, tidak setuju skor 2, netral skor 3, setuju skor 4, dan sangat setuju skor 5).

Tabel 1. Pengukuran Etika Penggelapan Pajak (Y).

\begin{tabular}{|c|c|c|c|}
\hline Variabel & Indikator & $\begin{array}{c}\text { Jumlah } \\
\text { Pernyataan }\end{array}$ & Skala \\
\hline \multirow{4}{*}{$\begin{array}{c}\text { Etika } \\
\text { Penggelapan } \\
\text { Pajak (Y) }\end{array}$} & $\begin{array}{l}\text { Pentingnysa kerja sama antara wajib pajak dengan } \\
\text { fiskus dalam hal penerapan tarif dari pajak. }\end{array}$ & \multirow{4}{*}{5} & \multirow{4}{*}{ Likert } \\
\hline & $\begin{array}{l}\text { Peluang untuk wajib pajak melakukan pelanggaran } \\
\text { berupa penggelapan pajak sudah di anggap beretika } \\
\text { dan mencakup hal penggelapan pajak dikarenakannya } \\
\text { lemahnya hukum vang mengatur akan hal tersebut. }\end{array}$ & & \\
\hline & $\begin{array}{l}\text { Pendiskriminasian pada perlakuan perpajakan serta } \\
\text { dalam hal integritas atau juga mentalitas perpajakan } \\
\text { dan pejabat pemerintah yang buruk. }\end{array}$ & & \\
\hline & $\begin{array}{l}\text { Penggelapan pajak yang memiliki sebuah } \\
\text { konsekuensi. }\end{array}$ & & \\
\hline
\end{tabular}

(Su mber: Charles Silaen, 2015)

b. Variabel Independen (X)

Variabel independen didalam penelitian ini ialah diskriminasi pajak, pengetahuan perpajakan, dan norma subjektif. Pengertian diskriminasi menurut UU No. 39 Tahun 1999 tentang HAM ialah setiap pengucilan, pelecehan, pembatasan yang dilakukan secara sengaja ataupun tidak disengaja langsung atau tidak langsung yang didasari pada perbedaan individu yang menyangkut dasar dari agama, kelompok, suku, etnik, ras, status sosial, status dari ekonomi, golongan, bahasa, jenis kelamin, serta suatu keyakinan politik. Penelitian ini menggunakan instrumen pertanyaan Silaen (2015) untuk variabel diskriminasi pajak dan menggunakan skala likert (sangat tidak setuju skor 1, tidak setuju skor 2, netral skor 3, setuju skor 4, dan sangat setuju skor 5). 
Tabel 2. Pengukuran Diskriminasi Pajak $\left(\mathrm{X}_{1}\right)$.

\begin{tabular}{clrr}
\hline Variabel & \multicolumn{1}{c}{ Indikator } & Jumlah Pernyataan & Skala \\
\hline Diskriminasi Pajak & Kebudayaan, ras, & \\
$\left(\mathrm{X}_{1}\right)$ & agama, serta starta & & \\
& sosial menjadiak & & \\
& suatu diskriminasi. & & Likert \\
& Berbagai hal yang & 4 & \\
& menjadi sebuah & & \\
manfaat perpajakan & & \\
dijadikan suatu & & \\
& diskriminasi.. & \\
\hline
\end{tabular}

(Su mber: Charles Silaen, 2015)

Variabel selanjutnya pengetahuan perpajakan ialah keadaan wajib pajak dalam memiliki pengetahuan mengenai ketentuan umum dan tata cara perpajakan, sistem perpajakan, dan fungsi pajak (Wardani \& Wati, 2018). Instrumen pertanyaan (lihat Tabel 3) yang dikembangkan oleh Suminarsasi (2011) serta Wardani dan Wati (2018) dipakai pada penelitian ini untuk variabel pengetahuan perpajakan dan menggunakan skala likert (sangat tidak setuju skor 1, tidak setuju skor 2, netral skor 3, setuju skor 4, dan sangat setuju skor 5).

Tabel 3 Pengukuran Pengetahuan Perpajakan $\left(\mathrm{X}_{2}\right)$.

\begin{tabular}{|c|c|c|c|}
\hline Variabel & Indikator & Jumlah Pernyataan & Skala \\
\hline \multirow[t]{3}{*}{$\begin{array}{c}\text { Pengetahuan } \\
\text { Perpajakan }\left(\mathrm{X}_{1}\right)\end{array}$} & $\begin{array}{l}\text { Tata cara mengenai } \\
\text { perpajakan serta } \\
\text { pengetahuan tentang } \\
\text { ketentuan umum. }\end{array}$ & 9 & Likert \\
\hline & $\begin{array}{l}\text { Sistem mengenai } \\
\text { perpajakan yang ada } \\
\text { di Indonesia dalam } \\
\text { hal ini menyangkut } \\
\text { hal pengetahuan } \\
\text { akan sistemtersebut. }\end{array}$ & & \\
\hline & $\begin{array}{lr}\text { Fungsi } & \text { dari } \\
\text { perpajakan } & \text { itu } \\
\text { sendiri } & \text { yang } \\
\text { menyangkut } & \text { akan } \\
\text { pengetahuan } & \text { dari } \\
\text { fungsitersebut. } & \end{array}$ & & \\
\hline
\end{tabular}

(Su mber:Wardani \& Wati, 2018)

Variabel independent yaitu norma subjektif. Menurut Jogiyanto (2007), norma subjektif yaitu suatu pandangan yang timbul dari seseorang terhadap kepercayaan individu lain atau orang lain dan mampu memberi pengaruh terhadap suatu minat agar dapat berpengaruh dalam pengambilan keputusan untuk melakukan atau tidak dalam perilaku yang saat itu di pertimbangkan. Instrumen pertanyaan (lihat Tabel 4) yang dikembangkan oleh Fatimah dan Wardani (2017) dipakai pada penelitian ini untuk variabel norma subjektif dan menggunakan 
Studi Akuntansi \& Keuangan Indonesia

skala likert (sangat tidak setuju skor 1, tidak setuju skor 2, netral skor 3, setuju skor 4, dan sangat setuju skor 5).

Tabel 4 Pengukuran Norma Subjektif $\left(\mathrm{X}_{3}\right)$.

\begin{tabular}{clcc}
\hline Variabel & \multicolumn{1}{c}{ Indikator } & Jumlah Pernyataan & Skala \\
\hline $\begin{array}{c}\text { Norma Subjektif } \\
\left(\mathrm{X}_{3}\right)\end{array}$ & $\begin{array}{l}\text { Pengaruh dari } \\
\text { petugas pajak }\end{array}$ & & Likert \\
\cline { 2 - 2 } & $\begin{array}{l}\text { Pengaruh dari } \\
\text { konsultan pajak. }\end{array}$ & & \\
\cline { 2 - 2 } & $\begin{array}{l}\text { Pengaruh dari } \\
\text { keluarga }\end{array}$ & & \\
& Pengaruh dari teman. & & \\
&
\end{tabular}

(Su mber:Fatimah \&Wardani, 2017)

Penelitian ini menggunakan data primer. Sumber data diperoleh langsung dari responden tanpa adanya perantara yang dapat menghasilkan sebuah opini orang yang berbeda-beda. Hipotesis penelitian ini menggunakan regresi linear berganda yang datanya diolah dengan aplikasi Smart PLS versi 3.0. Populasi yang terdapat pada penelitian ini sendiri merupakan individu wajib pajak dan telah terdaftar pada KPP Pratama Jabodetabek. Sedangkan sampel yang didapatkan dan dapat diolah oleh peneliti sebanyak 100 wajib pajak dari 119 wajib pajak. Sampel yang diambil memakai teknik berupa non-probability sampling dengan metode snowball sampling dalam penyebaran kuesioner yang dilakukan pada bulan April sampai bulan Mei tahun 2020. Dalam penelitian yang dilakukan ini untuk pengambilan sampel sendiri mempunyai kriteria-kriteria tertentu. Penjabaran daftar perolehan sampel dapat dilihat pada Tabel 5.

Tabel 5 Proses Seleksi Sampel

\begin{tabular}{clc}
\hline No. & \multicolumn{1}{c}{ Kriteria } & Jumlah \\
\hline 1 & Banyaknya kuesioner yang didapatkan & 119 \\
\hline 2 & Banyaknya kuesioner yang tidak me miliki NPWP & 0 \\
\hline 3 & $\begin{array}{l}\text { Banyaknya kuesioner yang belum me miliki } \\
\text { pengalaman kerja diatas 2 tahun }\end{array}$ & 0 \\
\hline 4 & Jumlah kuesioner yang outlier & $(19)$ \\
\hline & Total Kuesioner yang diuji & 100 \\
\hline
\end{tabular}

Demografi responden meliputi beberapa kategori atau jenis didalamnya seperti usia, kelamin, pendidikan terakhir, serta pekerjaan apa yang diambil 100 responden tersebut di bawah ini merupakan gambaran dari demografi responden yang berkaitan dengan kategori di atas yaitu: 
Studi Akuntansi \& Keuangan Indonesia

Tabel 6 Demografi Responden

\begin{tabular}{|c|c|c|c|}
\hline Karakteristik & Keterangan & Frekuensi & Presentase \\
\hline Lama Jadi WP & Lebih dari 2 Tahun & 100 & $100 \%$ \\
\hline \multirow{2}{*}{ Jenis Kelamin } & Laki-Laki & 53 & $53 \%$ \\
\hline & Pere mpuan & 47 & $47 \%$ \\
\hline Total & & 100 & $100 \%$ \\
\hline \multirow{5}{*}{ Usia } & 20 s/d 24 Tahun & 33 & $33 \%$ \\
\hline & 25 s/d 29 Tahun & 23 & $23 \%$ \\
\hline & 30 s/d 34 Tahun & 17 & $17 \%$ \\
\hline & 35 s/d 49 Tahun & 19 & $19 \%$ \\
\hline & Diatas 50 Tahun & 8 & $8 \%$ \\
\hline Total & & 100 & $100 \%$ \\
\hline \multirow{5}{*}{ Pendidikan Terakhir } & SMU atau Kurang & 41 & $41 \%$ \\
\hline & Dip loma & 6 & $6 \%$ \\
\hline & Sarjana (S1) & 42 & $42 \%$ \\
\hline & Pascasarjana (S2) & 11 & $11 \%$ \\
\hline & Doktor (S3) & 0 & $0 \%$ \\
\hline Total & & 100 & $100 \%$ \\
\hline \multirow{4}{*}{ Jenis Pekerjaan } & Wiras wasta & 4 & $4 \%$ \\
\hline & Pegawai Swasta & 52 & $52 \%$ \\
\hline & Pegawai Negeri & 23 & $23 \%$ \\
\hline & Lainnya & 21 & $21 \%$ \\
\hline Total & & 100 & $100 \%$ \\
\hline Total Keseluruhan & & 100 & $100 \%$ \\
\hline
\end{tabular}

\section{Hasil dan Diskusi}

\section{Tabel 7 Hasil Uji Statistik Deskriptif}

\begin{tabular}{lcccccc}
\hline \multicolumn{1}{c}{ Variabel } & $\mathrm{N}$ & $\begin{array}{c}\text { Total Item } \\
\text { Pertanyaan }\end{array}$ & Mean & Median & Modus & STDV \\
\hline Diskriminasi Pajak & 100 & 4 & 13.42 & 13.00 & 12 & 3.169 \\
\hline $\begin{array}{l}\text { Pengetahuan } \\
\text { Perpajakan }\end{array}$ & 100 & 9 & 36.16 & 37.00 & 41 & 4.741 \\
\hline Norma Subjektif & 100 & 4 & 14.58 & 15.00 & 16 & 3.340 \\
\hline $\begin{array}{l}\text { Etika Penggelapan } \\
\text { Pajak }\end{array}$ & 100 & 5 & 19.80 & 20.00 & 20 & 3.846 \\
\hline
\end{tabular}

Berdasarkan Tabel 7, nilai rata-rata variabel diskriminasi pajak yaitu 13.42 yang jika dibagi 4 sesuai dengan jumlah item pertanyaan yang ada, akan mendapatkan hasil 
Studi Akuntansi \& Keuangan Indonesia

sebesar 3.35 terletak pada pilihan jawaban netral. Artinya persepsi wajib pajak terkait adanya diskriminasi pajak adalah netral. Dengan kata lain, wajib pajak memandang bahwa tindakan diskriminasi pajak dalam perpajakan masih berlaku dan juga ada yang memandang bahwa tindakan diskriminasi pajak dalam perpajakan sudah tidak ada.

Nilai rata-rata variabel pengetahuan perpajakan yaitu 36.16 yang jika dibagi 9 sesuai dengan jumlah item pertanyaan yang ada, akan mendapatkan hasil sebesar 4.01 atau responden menjawab setuju. Artinya bahwa wajib pajak telah mengetahui hal-hal yang bersangkutan dengan perpajakan, seperti tata cara perpajakan, sistem perpajakan, fungsi perpajakan, dan lainnya.

Selanjutnya nilai rata-rata variabel norma subjektif sendiri memperoleh nilai 14.58 yang jika dibagi 4 sesuai dengan jumlah item pertanyaan yang ada, akan mendapatkan hasil sebesar 3.64 atau netral tapi cenderung setuju. Artinya lingkungan sekitar WPOP cenderung mendorong wajib pajak untuk mematuhi ketentuan perpajakan

Nilai rata-rata variabel etika penggelapan pajak yaitu sebesar 19.80 yang jika dibagi 5 (sejumlah item pertanyaan yang ada), akan mendapatkan hasil sebesar 3.96. Artinya responden menjawab netral yang sangat cenderung setuju bahwa tindakan atas penggelapan pajak termasuk suatu perbuatan yang tidak beretika untuk dilakukan.

Tabel 8 Fornell-Larcker Criterion

\begin{tabular}{lcccc}
\hline & $\begin{array}{c}\text { Diskriminasi Pajak } \\
\text { (X1) }\end{array}$ & $\begin{array}{c}\text { Etika Penggelapan } \\
\text { Pajak(Y) }\end{array}$ & $\begin{array}{c}\text { Norma Subjekt if } \\
\text { (X3) }\end{array}$ & $\begin{array}{c}\text { Pengetahuan } \\
\text { Perpajakan (X2) }\end{array}$ \\
\hline DP & 1.000 & & & \\
\hline EPP & 0.391 & 0.834 & 0.741 & \\
\hline NS & 0.125 & 0.288 & 0.437 & 0.716 \\
\hline PP & 0.272 & 0.373 & & \\
\hline
\end{tabular}

Pada tabel 8 diatas menyatakan bahwa discriminant validity melalui fornell-larcker criterion telah memiliki nilai diatas dari 0.5 untuk konstruk yang dimiliki pada masing-masing variabel sehingga telah terpenuhi persyaratan untuk validitas konvergen (Ghozali \& Hengky, 2015). Dari variabel diskriminasi pajak memperoleh hasil 1.000, variabel etika penggelapan pajak memperoleh hasil sebesar 0.834, untuk variabel norma subjektif sendiri memperoleh hasil 0.741 , dan variabel pengetahuan perpajakan mendapatkan hasil sebesar 0.716. Maka dapat ditarik kesimpulan bahwa seluruh konstruk pada setiap variabel dinyatakan valid. 
Studi Akuntansi \& Keuangan Indonesia

Tabel 9 Adjusted R-square dan Hasil Uji PLS Algoritma Path dan Bootstrapping

\begin{tabular}{|c|c|c|c|c|c|}
\hline & $\begin{array}{l}\text { Original } \\
\text { Sample } \\
\text { (O) }\end{array}$ & $\begin{array}{c}\text { Sample } \\
\text { Mean. (M) }\end{array}$ & $\begin{array}{l}\text { Standard } \\
\text { Deviation. } \\
\text { (STDV) }\end{array}$ & T.Statistik & P.Value \\
\hline $\operatorname{DP}(\mathrm{X} 1)->\operatorname{EPP}(\mathrm{Y})$ & 0,312 & 0,311 & 0,112 & 2,784 & 0,006 \\
\hline $\mathrm{PP}(\mathrm{X} 2)->\operatorname{EPP}(\mathrm{Y})$ & 0,222 & 0,251 & 0,126 & 1,759 & 0,079 \\
\hline \multirow[t]{2}{*}{$\mathrm{NS}(\mathrm{X} 3)$-> EPP(Y) } & 0,152 & 0,183 & 0,184 & 0,822 & 0,411 \\
\hline & & \multicolumn{2}{|c|}{ Adjusted R-Square } & & \\
\hline \multicolumn{2}{|c|}{ Etika Penggelapan Pajak (Y) } & & $\underline{0.225}$ & & \\
\hline
\end{tabular}

Nilai Adjusted R-Square pada Tabel 9 menunjukkan bahwa diskriminasi pajak, pengetahuan perpajakan, dan norma subjektif mempengaruhi etika penggelapan pajak sebesar 0.225 atau $22.5 \%$ dan sisanya sebesar $77.5 \%$ dipengaruhi oleh faktor-faktor lain diluar penelitian ini seperti tarif pajak, sistem perpajakan, pemahaman perpajakan, dan sebagainya.

Kemudian pada hasil uji PLS Algoritma Path dan Bootstrapping telah menunjukkan hasil pengujian atas variabel diskriminasi pajak terhadap etika penggelapan pajak yang menunjukkan bahwa $t_{\text {hitung }}>t_{\text {tabel }}$ sebesar $2.784>1.98498$ dan mendapatkan perolehan signifikansi sebesar $0.006<0.05$ yang artinya diskriminasi pajak memiliki pengaruh secara signifikan terhadap etika penggelapan pajak dalam persepsi wajib pajak orang pribadi. Perolehan hasil tersebut sejalan dengan telaah yang dilakukan Dewi dan Merkusiwati (2017) serta penelitian Monica dan Arisman (2018), yang menunjukkan bahwa diskriminasi pajak berpengaruh positif pada etika penggelapan pajak. Masyarakat merasa masih terdapat tindakan yang diberikan oleh aparatur pajak atau didalam anjuran yang telah dibuat oleh pemerintah yang dapat membeda-bedakan masyarakat saat membayar pajak. Hal ini mempengaruhi masyarakat untuk melakukan tindakan pengge lapan pajak dan berpersepsi tindakan tersebut etis meskipun dapat merugikan negara.

Selain itu juga ada pengetahuan perpajakan terhadap etika penggelapan pajak, dari hasil olah data terlihat bahwa $t_{\text {hitung }}<t_{\text {tabel }}$ sebesar $1.759<1.98498$ dan nilai signifikansi sebesar 0.079 $>0.05$. Artinya pengetahuan perpajakan tidak memiliki pengaruh secara signifikan terhadap etika penggelapan pajak dalam persepsi wajib pajak orang pribadi. Hasil penelitian ini tidak sejalan dengan hasil penelitian Putri (2017) dan Febri dan Sulistiyani (2018) mendapatkan hasil bahwa pengetahuan perpajakan berpengaruh positif terhadap etika pelanggaran pajak. Kemungkinan hasil penelitian ini tidak berpengaruh disebabkan persepsi dari jawaban responden. Karena berdasarkan analisis deskriptif, rata-rata responden sebagai wajib pajak menjawab cenderung setuju pada pengetahuan terkait perpajakan dan responden menjawab netral yang cenderung setuju terkait pengge lapan pajak merupakan tindakan tidak beretika. 
Studi Akuntansi \& Keuangan Indonesia

Terakhir ada norma subjektif terhadap etika penggelapan pajak yang menunjukkan bahwa $\mathrm{t}_{\text {hitung }}<\mathrm{t}_{\text {tabel }}$ sebesar $0.822<1.98498$ dengan nilai signifikansi sebesar $0.441>0.05$. Hal ini menunjukkan bahwa norma subjektif tidak memiliki pengaruh secara signifikan terhadap etika penggelapan pajak dalam persepsi wajib pajak orang pribadi. Sesuai dengan hasil penelitian Fatimah dan Wardani (2017) serta Surahman dan Putra (2018), yang mendapatkan hasil bahwa norma subjektif tidak berpengaruh terhadap persepsi wajib pajak mengenai etika penggelapan pajak. Kemungkinan norma subjektif tidak memiliki pengaruh terhadap penggelapan pajak disebabkan karena individu sendiri berada di dalam kekuatan sosial yang rendah. Rendahnya kekuatan sosial disini dapat diartikan jika wajib pajak melakukan pembayaran pajak, maka individu tersebut berpikir keuntungan apa yang akan didapatkan dari pemerintah apabila dia membayar pajak. Hal ini didukung dengan jawaban responden yang cenderung setuju bahwa lingkungan sekitar cenderung mendorong WPOP untuk mematuhi ketentuan perpajakan.

\section{Kesimpulan, Implikasi, dan Keterbatasan}

Berdasarkan hasil dapat disimpulkan bahwa diskriminasi pajak berpengaruh signifikan terhadap etika pengge lapan pajak. Semakin tinggi diskriminasi pajak yang dipersepsikan oleh wajib pajak, maka WPOP akan menilai bahwa tindakan atas penggelapan pajak semakin etis atau beretika untuk dilakukan. Dapat diartikan juga bahwa setiap kebijakan yang akan dirancang oleh pemerintah jangan hanya akan menguntungkan sebagian kelompok dari masyarakat, yang nantinya akan menimbulkan kecemburuan pada masyarakat.

Pengetahuan perpajakan tidak memiliki pengaruh secara signifikan terhadap etika pengge lapan pajak. Hal ini menunjukkan bahwa setiap wajib pajak yang memiliki ataupun tidak memiliki pengetahuan perpajakan, akan tetap berpersepsi bahwa tindakan pengge lapan pajak itu tidak etis (tidak beretika).

Norma subjektif tidak berpengaruh secara signifikan terhadap etika penggelapan pajak. Lingkungan sosial yang ada disekitar wajib pajak seperti keluarga, teman, petugas pajak, konsultan pajak, ataupun media cetak lainnya belum mampu dapat mempengaruhi niat dari masing-masing WPOP untuk melakukan tindakan yang sesuai dengan peraturan perpajakan.

Implikasi penelitian, perlunya sosialisasi kepada masyarakat mengenai perpajakan secara lebih detail lagi. Hal ini agar masyarakat sebagai wajib pajak dapat memahami, dan patuh dalam peraturan yang telah diberikan oleh pemerintah. Dengan demikian, WPOP tidak memiliki persepsi adanya diskriminasi pajak dan tidak ada yang merasa etis pada tindakan penggelapan pajak.

Keterbatasan penelitian ini terdapat pada teknik pengumpulan data yang dimana penulis menggunakan kuesioner dalam bentuk gfrom dan penyebaran kuesioner dengan metode snowball. Sehingga peneliti tidak bisa memastikan secara langsung keabsahan jawaban responden saat diis $i$. 
Studi Akuntansi \& Keuangan Indonesia

Hal ini dapat menimbulkan bias, karena adanya perbedaan persepsi antara responden dengan peneliti, sehingga responden dalam menjawab tidak menggambarkan keadaan yang sebenarnya.

Saran untuk penelitian selanjutnya, dapat dilakukan wawancara kepada responden selain menyebarkan kuesioner juga. Dengan demikian, dapat dihasilkan jawaban responden yang lebih mendalam lagi, dibanding dengan melakukan penyebaran kuesioner saja. Menambahkan variabelvariabel independen untuk melakukan penelitian etika pengge lapan pajak, seperti: sistem perpajakan, keadilan, intensitas pemeriksaan pajak, kualitas pelayanan, dan sebagainya. Menambahkan jumlah responden serta memperluas penyebaran dalam kuesioner, sehingga dapat menghasilkan penelitian yang lebih baik.

\section{DAFTAR PUSTAKA}

Ajzen, I. (1991). The Theory of Planned Behavior. Organizational Behavior and Human Decision Processes. 50 (2), 178-211,

Ajzen, I. (2005). Attitudes, Personality and Behavior. International Journal of Strategic Innovative Marketing, 3(2), 1-191.

Alvin, A. (2014). Pengaruh Sikap, Norma Subyektif, Dan Kontrol Perilaku Yang Dipersepsikan Staff Pajak Terhadap Kepatuhan Pajak Wajib Pajak Badan Tax \& Accounting Review, 4 (1), 1-12.

Asih, N.P.S.M., \& Dwiyanti, K.T. (2019). Pengaruh Love Of Money, Machiavellian, Dan Equity Sensitivity Terhadap Persepsi Etika Penggelapan Pajak (Tax Evasion), E-Jurnal Akuntansi, 26(2), 1412-1435. doi: 10.24843/eja.2019.v26.i02.p21

Dewi, N.K.T.J., \& Merkusiwati, N.K.L.A. (2017). Faktor-Faktor Yang Memengaruhi Persepsi Wajib Pajak Mengenai Etika Atas Penggelapan Pajak (Tax Evasion) Fakultas Ekonomi Dan Bisnis Universitas Udayana ( Unud ), Bali, Indonesia Fakultas Ekonomi Dan Bisnis Univers. E-Jurnal Akuntansi Universitas Udayana, 18(3), 2534-2564.

Faradiza, S, A. (2018). Persepsi Keadilan, Sistem Perpajakan Dan Diskriminasi Terhadap Etika Penggelapan Pajak. Jurnal Ilmu Akuntansi, 11(1), 53-74. doi: 10.15408/akt.v11i1.8820

Fatimah, S., \& Wardani, D.K. (2017). Faktor-Faktor Yang Mempengaruhi Penggelapan Pajak Di Kantor Pelayanan Pajak Pratama Temanggung. Akuntansi Dewantara, 1(1), $1-14$.

Febri, D., \& Sulistiyani, T.T. (2018). Pengaruh Pengetahuan dan Pemahaman Peraturan Perpajakan, Penghindaran Pajak dan Sanksi Perpajakan Terhadap Kepatuhan Wajib Pajak (Studi Pada Wajib Pajak Orang Pribadi Di Wilayah KPP Pratama Kota Tegal). Permana, 10(1), 15-26. 
Studi Akuntansi \& Keuangan Indonesia

Ghozali, I., \& Hengky, L. (2015). Partial Least Squares Konsep, Teknik dan Aplikasi Menggunakan Program SmartPLS 3.0 Untuk Penelitian Empiris. In: 2nd ed. Semarang: Universitas Diponegoro.

Ghozali, I. (2014). Structural Equation Modelling, Metode Alternatif Dengan Partial Least Square (PLS). 4th ed. Semarang: Universitas Diponegoro.

Hameed, H., A. (1983). Aspek-Aspek Pokok Agama Islam. 1st ed. Jakarta: Dunia Pustaka.

Ilhamsyah, R., Endang, M.D.W., \& Dewantara, R.Y. (2016). Pengaruh Pemahaman Dan Pengetahuan Wajib Pajak Tentang Peraturan Perpajakan, Kesadaran Wajib Pajak, Kualitas Pelayanan, Dan Sanksi Perpajakan Terhadap Kepatuhan Wajib Pajak Kendaraan Bermotor. Jurnal Perpajakan (JEJAK), 8(1), 1-9.

Indriyani, M., Nurlaela, S., \& Wahyuningsih, E, M. (2016). Pengaruh Keadilan, Sistem Perpajakan, Diskriminasi Dan Kemungkinan Terdeteksinya Kecurangan Terhadap Persepsi Wajib Pajak Orang Pribadi Mengenai Perilaku Tax Evasion. Prosiding Seminar Nasional IENACO, hlm. 818-25.

Jogiyanto. (2007). Sistem Informasi Keperilakuan. Edisi Revisi. Yogyakarta: Andi Offset.

Kementerian Keuangan Republik Indonesia. (2019). APBN KITA Kinerja Dan Fakta. 1-69.

Diakses 2 Maret 2020, dari https://www.kemenkeu. go.id/media/12483/apbn-kita-mei2019.pdf.

Koranperdjoeangan.com. (2019). Diskriminasi Kepada Pekerja Wanita Terus Mengintai, Bahkan PPh 21 Mencoba Ikut Mencengkeram. Diakses 11 Maret 2020, dari https://www.koranperdjoeangan.com/diskriminasi-kepada-pekerja-wanita-terusmengintai-bahkan-pph-21-mencoba-ikut-mencengkeram/.

Kumorotomo, W. (1994). Etika Administrasi Negara. 2nd ed. Jakarta: Raja Grafindo Persada.

Kwarto, F., Zulhazmi, A, B. (2019). Pengaruh penerapan sistem e-filing pengetahuan perpajakan dan kesadaran wajib pajak terhadap kepatuhan wajib pajak (studi pada wajib pajak orang pribadi yang melakukan kegiatan usaha bebas di bintaro trade center). Jurnal Riset Bisnis, 3(1), 20-29.

Marlina. (2018). Analisis Faktor-Faktor Yang Mempengaruhi Persepsi Wajib Pajak Orang Pribadi Mengenai Penggelapan Pajak pada KPP Pratama Lubuk Pakam. Jurnal Pundi, 2 (2), hlm. 151-168. doi: 10.31575/jp.v2i2.82

Monica, T., \& Arisman, A. (2018). Pengaruh Keadilan Pajak, Sistem Perpajakan, Dan Diskriminasi Pajak Terhadap Persepsi Wajib Pajak Orang Pribadi Mengenai Etika Penggelapan Pajak (Tax Evasion) (Studi Empiris Pada Kantor Pelayanan Pajak Pratama Seberang Ulu Kota Palembang). Jurnal Akuntansi, 1-13.

Mujiyati, Rohmawati, F.R., \& Ririn, W, H. (2018). Determinan Persepsi Mengenai Etika Atas Penggelapan Pajak (Tax Evasion). Riset Akuntansi dan Keuangan Indonesia 3 (1): 
Studi Akuntansi \& Keuangan Indonesia

$1-12$.

Oktaviani, R.M., Srimindarti, C., \& Hardiningsih, P. (2018). Peran Religiosity Sebagai Pemoderasi Hubungan Money Ethics Terhadap Upaya Tax Evasion. Jurnal Akuntansi, XXII (1), 105-118.

Palil, M.R., Malek, M.M., \& Jaguli, A.R. (2016). Issues, Challenges and Problems with Tax Evasion: The Institutional Factors Approach. Gadjah Mada International Journal of Business, 18 (2), 187-206.

Pratiwi, E., \& Prabowo, R. (2019). Keadilan dan Diskriminasi Pajak Terhadap Penggelapan Pajak: Persepsi Wajib Pajak Orang Pribadi. AFRE (Accounting and Financial Review), 2 (1), 8-15. doi: 10.26905/afr.v2i1.3008

Pulungan, R.H. (2015). Pengaruh Keadilan, Sistem Perpajakan, Dan Kemungkinan Terdeteksinya Kecurangan Terhadap Persepsi Wajib Pajak Mengenai Etika Penggelapan Pajak (Tax Evasion). Jom. FEKON, 2 (2), 1-14.

Putra, I, M. (2019). Pengantar Komplet Akuntansi Dan Perpajakan. Yogyakarta.

Putri, H. (2017). Pengaruh Sistem Perpajakan, Diskriminasi, Kepatuhan dan Pengetahuan Perpajakan Terhadap Persepsi Wajib Pajak Mengenai Etika Penggelapan Pajak (Studi Empiris Pada Wajib Pajak Orang Pribadi Di Wilayah Kota Pekanbaru). Jom. FEKON, 4 (1), 2045-58.

Ramdhani, M. A. (2019). Etika Administrasi. 1st ed. Bandung: CV Pustaka Setia.

Salam, B. (2000). Etika Individual: Pola Dasar Filsafat Moral. 1st ed. Jakarta: Rineka Cipta.

Sariani, P., Wahyuni, M.A., \& Sulindawati, N.L.G.E. (2016). Pengaruh Keadilan, Sistem Perpajakan, Diskriminasi, Dan Biaya Kepatuhan Terhadap Persepsi Wajib Pajak Mengenai Etika Penggelapan Pajak (Tax Evasion) Pada KPP Pratama Singaraja. ejournal S1 Ak Universitas Pendidikan Ganesha, 6 (3).

Seralurin, Y.C., \& Ermawati, Y. (2019). Influence of Self-Assessment System, Taxation Understanding, and Discrimination Toward Ethics of Tax Evasion: A Case in Papua Indonesia. International research journal of management, IT and social sciences, 6 (5), 267-278. doi: 10.21744/irjmis.v6n5.745

Silaen, C. (2015). Pengaruh Sistem Perpajakan, Diskriminasi, Teknologi Dan Informasi Perpajakan Terhadap Persepsi Wajib Pajak Mengenai Etika Penggelapan Pajak (Tax Evasion). Jom. FEKON, 2 (2), 1-15.

Solekhah, P., Supriono, S. (2018). Pengaruh Penerapan Sistem E-Filing, Pemahaman Perpajakan, Kesadaran Wajib Pajak dan Sanksi Perpajakan Terhadap Kepatuhan Wajib Pajak Orang Pribadi di KPP Pratama Purworejo. J Econ Manag Account Technol, 1(1), 74-90. doi: 10.32500/jematech.v1i1.214

Sugiyono. (2014). Metode Penelitian Kuantitatif Kualitatif Dan R\&D. Bandung: Alfabeta. 
Studi Akuntansi \& Keuangan Indonesia

Suminarsasi, W., \& Supriyadi. (2011). Pengaruh Keadilan, Sistem Perpajakan, Dan Diskriminasi Terhadap Persepsi Wajib Pajak Mengenai Etika Penggelapan Pajak (Tax Evasion). PPJK 15 Universitas Gadjah Mada, 1 (2), 1-29.

Surahman, W, \& Putra, U.Y. (2018). Faktor-Faktor Persepsi Wajib Pajak Terhadap Etika Penggelapan Pajak. Jurnal REKSA: Rekayasa Keuangan, Syariah dan Audit, 5 (1), 110.

Suryani, L. (2017). Pengaruh Sikap, Norma Subjektif, dan Kontrol Perilaku Persepsian Terhadap Kepatuhan Wajib Pajak Orang Pribadi Di Daerah Istimewa Yogyakarta Dengan Niat Mematuhi Pajak Sebagai Variabel Pemoderasi. Jurnal Profita, 3 (5), 120.

Suryani, L. (2017). Pengaruh Sikap, Norma Subjektif, dan Kontrol Perilaku Persepsian Terhadap Kepatuhan Wajib Pajak Orang Pribadi Di Daerah Istimewa Yogyakarta Dengan Niat Mematuhi Pajak Sebagai Variabel Pemoderasi. Jurnal Profita, Volume 3(5), hlm. 1-20.

Umam, K. (2019). Etika Administrasi. 1st ed. Bandung: CV Pustaka Setia.

Wanarta, E.F., \& Mangoting, Y. (2014). Pengaruh Sikap Ketidakpatuhan Pajak, Norma Subjektif, Dan Kontrol Perilaku Yang Dipersepsikan Terhadap Niat Wajib Pajak Orang Pribadi Untuk Melakukan Penggelapan Pajak. Tax \& Accounting Review, 4 (1), 1-13.

Widjaja, P.N.K., Lambey, L., \& Walandouw, S.K. (2017). Pengaruh Diskriminasi Dan Pemeriksaan Pajak Terhadap Persepsi Wajib Pajak Orang Pribadi Mengenai Penggelapan Pajak Di Kota Bitung (Studi Kasus Pada WPOP Yang Ditemui Di KPP Pratama Bitung). Jurnal Riset Akuntansi Going Concern, 12 (2), 541-552.

Wulandari, E., Maslichah, \& Mawardi, M.C. (2019). Determinasi Persepsi Wajib Pajak Mengenai Etika Penggelapan Pajak (Studi Empiris pada WPOP yang terdaftar di KPP Pratama Malang Utara). E-JRA, 09 (05), 129-142. 


\section{LAMPIRAN}

DAFTAR PERTANYAAN

DAFTAR PERTANYAAN UNTUK VARIABEL DEPENDEN

\begin{tabular}{|c|c|c|c|c|c|c|}
\hline \multicolumn{7}{|c|}{ Etika Penggelapan Pajak } \\
\hline No. & Pertanyaan & STS & TS & $\mathbf{N}$ & $\mathbf{S}$ & SS \\
\hline 1. & $\begin{array}{l}\text { Menurut saya, penggelapan pajak adalah } \\
\text { tindakan yang etis apabila tarif pajak yang } \\
\text { ditetapkan terlalu tinggi. }\end{array}$ & & & & & \\
\hline 2. & $\begin{array}{l}\text { Menurut saya, penggelapan pajak tidak etis } \\
\text { meskipun saya tidak secara langsung } \\
\text { merasakan manfaat dari uang pajak yang saya } \\
\text { setor. }\end{array}$ & & & & & \\
\hline 3. & $\begin{array}{l}\text { Menurut saya, penggelapan pajak tidak etis } \\
\text { meskipun pemerintahnya korupsi. }\end{array}$ & & & & & \\
\hline 4. & $\begin{array}{l}\text { Menurut saya, penggelapan pajak tidak etis } \\
\text { meskipun uang pajak yang terkumpul tidak } \\
\text { dikelola untuk membiayai pengeluaran untuk } \\
\text { pembiayaan rutin seperti belanja pegawai, } \\
\text { belanja barang, pemeliharaan, dan } \\
\text { sebagainya. }\end{array}$ & & & & & \\
\hline 5. & $\begin{array}{l}\text { Menurut saya, penggelapan pajak tidak etis } \\
\text { meskipun terdapat diskriminasi dalam } \\
\text { perpajakan. }\end{array}$ & & & & & \\
\hline
\end{tabular}

DAFTAR PERTANYAAN UNTUK VARIABEL INDEPENDEN

\section{Diskriminasi Pajak}

\begin{tabular}{|c|l|c|c|c|c|c|}
\hline No. & \multicolumn{1}{|c|}{ Pertanyaan } & STS & TS & N & S & SS \\
\hline 1. & $\begin{array}{l}\text { Menurut saya, membedakan pelayanan } \\
\text { berdasarkan gender atau status merupakan } \\
\text { suatu bentuk diskriminasi. }\end{array}$ & & & & & \\
\hline 2. & $\begin{array}{l}\text { Menurut saya, zakat diperbolehkan sebagai } \\
\text { faktor pengurang penghasilan kena pajak } \\
\text { yang merupakan sebagai suatu bentuk } \\
\text { diskriminasi. }\end{array}$ & & & & & \\
\hline
\end{tabular}




\begin{tabular}{|c|l|l|l|l|l|l|}
\hline 3. & $\begin{array}{l}\text { Menurut saya, bantuan dan sumbangan selain } \\
\text { zakat tidak diperbolehkan sebagai pengurang } \\
\text { pajak yang merupakan suatu bentuk } \\
\text { diskriminasi }\end{array}$ & & & & & \\
\hline 4. & $\begin{array}{l}\text { Menurut saya, dengan adanya zona bebas } \\
\text { pajak yang merupakan bebas dari bea masuk, } \\
\text { bea cukai, dan PPn merupakan suatu bentuk } \\
\text { diskriminasi. }\end{array}$ & & & & \\
\hline
\end{tabular}

\begin{tabular}{|c|c|c|c|c|c|c|}
\hline \multicolumn{7}{|c|}{ Pengetahuan Perpajakan } \\
\hline No. & Pertanyaan & STS & TS & $\mathbf{N}$ & $\mathbf{S}$ & SS \\
\hline 1. & $\begin{array}{l}\text { Saya telah mengetahui ketentuan terkait } \\
\text { kewajiban perpajakan yang berlaku. }\end{array}$ & & & & & \\
\hline 2. & $\begin{array}{l}\text { Saya telah mengetahui seluruh peraturan } \\
\text { mengenai batas waktu pelaporan SPT. }\end{array}$ & & & & & \\
\hline 3. & $\begin{array}{l}\text { Saya paham dengan sistem perpajakan yang } \\
\text { digunakan saat ini (menghitung, memp } \\
\text { erhitungkan, membayar dan melaporkan } \\
\text { sendiri). }\end{array}$ & & & & & \\
\hline 4. & Tarif pajak yang berlaku saat ini sudah sesuai. & & & & & \\
\hline 5. & $\begin{array}{l}\text { Saya tidak paham mengenai sistem } \\
\text { perpajakan di Indonesia. }\end{array}$ & & & & & \\
\hline 6. & $\begin{array}{l}\text { NPWP berfungsi sebagai identitas Wajib } \\
\text { Pajak dan tiap wajib pajak harus memilikinya. }\end{array}$ & & & & & \\
\hline 7. & $\begin{array}{l}\text { Pajak berfungsi sebagai sumber penerimaan } \\
\text { negara terbesar. }\end{array}$ & & & & & \\
\hline 8. & $\begin{array}{l}\text { Pajak yang disetor dapat digunakan untuk } \\
\text { pembiayaan oleh pemerintah. }\end{array}$ & & & & & \\
\hline 9. & $\begin{array}{l}\text { Salah satu fungsi pajak adalah sebagai } \\
\text { sumber dana bagi negara untuk membiayai } \\
\text { pengeluaran rutin negara. }\end{array}$ & & & & & \\
\hline
\end{tabular}

\begin{tabular}{|c|l|l|l|l|l|c|}
\hline \multicolumn{1}{|l|}{ Norma Subjektif } \\
\hline No. & Pertanyaan & STS & TS & N & S & SS \\
\hline
\end{tabular}


Studi Akuntansi \& Keuangan Indonesia

\begin{tabular}{|c|l|l|l|l|l|l|}
\hline 1. & $\begin{array}{l}\text { Teman saya pernah mendorong untuk } \\
\text { mematuhi ketentuan perpajakan. }\end{array}$ & & & & \\
\hline 2. & $\begin{array}{l}\text { Keluarga saya pernah mendorong untuk } \\
\text { memenuhi ketentuan perpajakan. }\end{array}$ & & & & & \\
\hline 3. & $\begin{array}{l}\text { Konsultan pajak pernah membujuk saya } \\
\text { untuk mematuhi ketentuan perpajakan. }\end{array}$ & $\begin{array}{l}\text { Petugas pajak pernah membujuk saya untuk } \\
\text { mematuhiketentuan perpajakan. }\end{array}$ & & & & \\
\hline 4. & & & & & \\
\hline
\end{tabular}

